MaPan : Jurnal Matematika dan Pembelajaran

p-ISSN: 2354-6883 ; e-ISSN: 2581-172X

Volume 6, No 2, December 2018 (148-160)

DOI: https://doi.org/10.24252/mapan.2018v6n2a2

\title{
HUBUNGAN ANTARA KEMAMPUAN NUMERIK DENGAN KEMAMPUAN PEMECAHAN MASALAH MATEMATIS SISWA DI PEDESAAN
}

\author{
Bedilius Gunur1), Alberta Parinters Makur'), Apolonia Hendrice Ramda ${ }^{3)}$ \\ 1,2,3STKIP Santu Paulus Matematika \\ 1,2,3Jalan Ahmad Yani No. 10 Ruteng-Flores \\ E-mail: gbedilius@gmail.com ${ }^{1}$, alberta.makur@stkipsantupaulus.ac.id²), \\ apoloniahendrice@gmail.com ${ }^{3)}$
}

Submitted: 27-08-2018, Revised: 11-10-2018, Accepted: 08-12-2018

\begin{abstract}
Abstrak:
Penelitian ini bertujuan untuk mengetahui hubungan antara kemampuan numerik dengan kemampuan pemecahan masalah matematika siswa di daerah pedesaan. Penelitian ini menggunakan penelitian korelasional dengan populasi siswa kelas VIII SMP Negeri 1 Cibal yang terletak di Kecamatan Cibal Kabupaten Manggarai, Propinsi Nusa Tenggara Timur yang berjumlah 458 siswa. Sampel sebanyak 214 siswa dipilih dengan menggunakan teknik random sampling. Data diperoleh dari tes kemampuan pemecahan masalah matematika dan tes kemampuan numerik yang kemudian dianalisis dengan teknik analisis product moment. Analisis dan interpretasi data menunjukkan bahwa terdapat hubungan yang cukup kuat kemampuan numerik dengan kemampuan pemecahan masalah matematika siswa pedesaan. Selain itu, terdapat hubungan yang positif dan signifikan antara kemampuan numerik dengan kemampuan pemecahan masalah matematika. Kontribusi kemampuan numerik terhadap kemampuan pemecahan masalah matematika siswa sebesar 17,64\%.
\end{abstract}

Kata Kunci: Kemampuan Numerik, Pemecahan Masalah Matematika, Pedesaan

\section{THE CORRELATION BETWEEN NUMERICAL ABILITIES AND MATHEMATICAL PROBLEM SOLVING ABILITIESS OF THE STUDENTS IN RURAL AREA}

\begin{abstract}
:
The study aims to determine the correlation between numerical abilities and mathematical problem-solving abilities of the students in rural area. This study used correlational research with a population of eighth-grade students of SMP Negeri 1 Cibal of Manggarai regency, the Province of east Nusa Tenggara with total number of 458 students. The sample of 214 students had been selected by using random sampling technique. The data were obtained from mathematical problem-solving ability test and numerical ability tests, the data were then analyzed by using product moment analysis techniques. The analysis and interpretation of the data showed that: (1) the correlation between numerical ability and mathematical problem solving ability of the students in rural area was strong enough; (2) there was a positive and significant relationship between numerical ability and mathematical problem-solving ability.
\end{abstract}


The contribution of numerical ability to the students' mathematical problem-solving ability was $17.64 \%$.

Keywords: Numerical Ability, Mathematical Problem Solving Ability, Rural Area

How to Cite: Gunur, B., Makur, A. P., \& Ramda, A. H. (2018). Hubungan antara Kemampuan Numerik dengan Kemampuan Pemecahan Masalah Matematis Siswa di Pedesaan. MaPan : Jurnal Matematika dan Pembelajaran, 6(2), 148-160.

K emampuan pemecahan masalah merupakan salah satu kemampuan dasar yang perlu dimiliki oleh siswa. Suatu pertanyaan dikategorikan sebagai masalah apabila dalam penyelesaiannya membutuhkan pemikiran atau imajinasi, daya kreativitas, pemahaman dalam proses menemukan penyelesaian atau solusinya (Makur, Prahmana, \& Gunur, 2018). Masalah ini memacu seseorang untuk menyelesaikannya meskipun tidak secara langsung dapat diselesaikan. Kemampuan pemecahan masalah ini menjadi salah satu tujuan dalam pembelajaran matematika karena melibatkan pemikiran kritis, logis, dan sistematis (Fuadi, Minarni, \& Banjarnahor, 2017; Saragih \& Winmery, 2014)

Pemecahan masalah merupakan komponen penting dalam pendidikan abad 21 yang komprehensif dan dianggap sebagai jantung pembelajaran matematika. Keterampilan dalam menyelesaikan masalah tidak hanya digunakan untuk mempelajari subjek tetapi juga ditekankan pada pengembangan metode keterampilan berpikir (Eviyanti, Surya, Syahputra, \& Simbolon, 2017). Pembelajaran matematika yang menekankan pada peningkatan kemampuan pemecahan masalah akan membantu siswa dalam memahami hubungan antar konsep matematika maupun kaitan matematika dengan bidang ilmu lainnya (Lagur, Makur, \& Ramda, 2018). Kemampuan pemecahan masalah yang baik memungkinkan siswa membangun representasi masalah untuk mencapai pemahaman dan mendapatkan solusi dari permasalahan tersebut.

National Council of Teachers Mathematics (2000) mendefinisikan pemecahan masalah sebagai proses menerapkan pengetahuan yang telah diperoleh sebelumnya pada situasi baru dan berbeda. Lebih lanjut, Suherman (2001) menyatakan bahwa kemampuan pemecahan masalah adalah bagian penting dari kurikulum matematika karena dalam proses penyelesaiannya siswa memperoleh pengalaman mengaplikasikan pengetahuan serta 
kemampuan yang telah dimiliki untuk diterapkan pada masalah yang tidak rutin. Terlepas dari pentingnya kemampuan pemecahan masalah ini, beberapa penelitian terdahulu (Utami \& Wutsqa, 2017 ; Fuadi, Minarni, \& Banjarnahor, 2017) menemukan bahwa kemampuan pemecahan masalah matematika siswa masih dalam kategori yang sangat rendah.

Salah satu faktor rendahnya kemampuan pemecahan masalah siswa adalah rendahnya kemampuan numerik siswa (Indrawati, 2013; Suparlan, 2009). Suparlan (2009) mendefinisikan kemampuan numerik merupakan kemampuan menyelesaikan soal-soal matematika yang didalamnya termuat kemampuan melakukan pengerjaan-pengerjaan hitung. Lebih lanjut, Indrawati (2013) mengatakan tes kemampuan numerik dapat mengukur kemampuan intelektual seseorang terutama kemampuan penalaran berhitung dan berpikir secara logis. Kemampuan numerik adalah kemampuan intelektual seseorang dalam melakukan operasi perhitungan yang melibatkan proses berpikir logis dan sistematis.

Rendahnya kemampuan numerik dan kemampuan pemecahan masalah siswa SMP Negeri 1 Cibal dapat dilihat dari hasil wawancara dengan seorang guru matematika yang menyatakan bahwa kemampuan numerik dan pemecahan masalah matematika siswa SMP Negeri 1 Cibal perlu ditingkatkan. Guru matematika tersebut menjelaskan bahwa dalam keseharian siswa cukup sulit mengerjakan soal-soal matematika, siswa kesulitan bernalar dengan angka-angka, memanipulasi relasi dengan angka, berpikir logis, dan sistematis. Pernyataan ini juga didukung dengan tes awal yang dilakukan untuk mengetahui kemampuan siswa dalam mengerjakan soal matematika yang diberikan. $75 \%$ siswa masih kesulitan dalam menentukan strategi penyelesaian masalah bahkan sulit menalar dengan angka-angka. Sebagai contoh ketika disajikan soal matematika berikut. Hitunglah, keliling $\mathrm{AOB}$ dan luas bangun yang diarsir pada gambar berikut. Hasil pekerjaan siswa menunjukkan kesulitan dalam menentukkan strategi penyelesaian bahkan ada yang tidak memahami apa yang diketahui dan apa yang ditanyakan. Kenyataan ini mengindikasikan adanya hubungan antara

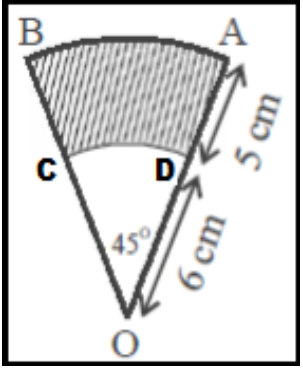
kemampuan numerik dengan kemampuan pemecahan masalah.

Selain kemampuan numerik dan kemampuan pemecahan masalah siswa, penelitian ini juga mengkaji keterkaitan kemampuan ini dengan kondisi siswa di daerah pedesaan. Walaupun secara IQ siswa di desa dan kota hampir merata, namun situasi tempat tinggal siswa juga berpengaruh dalam 150 | Volume 6, No 2, December 2018 
membentuk pola pikir dan semangat belajar (Graham \& Provost, 2012; Ramda, Prahmana, Gunur, \& Mulu, 2018). Terdapat perbedaan dalam kesempatan mendapatkan akses sumber belajar (buku, buku elektronik, permainan edukatif, dan alat peraga) dan pengalaman belajar (lomba, seminar, dan pertukaran pelajar). Oleh karen itu, dibutuhkan pengkajian secara empiris mengenai hubungan antara kemampuan numerik dengan kemampuan pemecahan masalah matematika siswa SMP Negeri 1 Cibal di daerah pedesaan.

\section{METODE PENELITIAN}

Penelitian ini merupakan penelitian korelasional ex post facto. Penelitian ini dilaksanakan di SMP Negeri 1 Cibal. Populasi dalam penelitian ini adalah seluruh siswa kelas VIII yang tersebar dalam delapan kelas yang berjumlah 458 siswa. Banyaknya sampel ditetapkan menggunakan rumus Yamane. Dengan tingkat kesalahan $\alpha=5 \%$, diperoleh ukuran sampel 214 siswa. Peneliti menggunakan teknik proportional random sampling untuk memperoleh unit sampel yang diambil dari setiap kelas. Instrumen yang digunakan untuk pengumpulan data adalah tes kemampuan pemecahan masalah matematika dan tes kemampuan numerik. Instrumen tes untuk mengukur kemampuan pemecahan masalah terdiri dari lima butir soal uraian sedangkan instrumen tes untuk mengukur kemampuan numerik terdiri dari 30 butir soal pilihan ganda. Kedua instrumen tersebut disusun berdasarkan indikator kemampuan pemecahan masalah matematika dan kemampuan numerik.

Sebelum digunakan, kedua instrumen tersebut diuji validitas dan reliabilitasnya. Pengujian validitas instrumen kemampuan pemecahan masalah matematika yang berbentuk uraian menggunakan rumus korelasi product moment sedangkan untuk instrumen kemampuan numerik yang berbentuk pilihan ganda menggunakan korelasi point biseral. Hasil uji validitas menunjukan bahwa kedua instrumen tersebut dinyatakan valid. Hasil uji validitas test kemampuan pemecahan masalah dapat dilihat pada tabel 1.

Tabel 1. Rekapitulasi Hasil Validitas Tes Kemampuan Pemecahan Masalah Matematika

\begin{tabular}{ccccc}
\hline No Butir & $\mathbf{r}_{\mathbf{x y}}$ & $\mathbf{r}_{\text {tabel }}$ & Keterangan & Keputusan \\
\hline 1 & 0,639 & 0,244 & Valid & Dipakai \\
\hline 2 & 0,589 & 0,244 & Valid & Dipakai \\
\hline 3 & 0,604 & 0,244 & Valid & Dipakai \\
\hline 4 & 0,538 & 0,244 & Valid & Dipakai \\
\hline
\end{tabular}




\begin{tabular}{|c|c|c|c|c|c|c|c|c|c|}
\hline 5 & & 0,5 & 74 & 0,244 & & Valid & & Dip & \\
\hline & Tab & al & it & 1101 & tiunte & Tes Ker & npuar & Numer & tabel 2. \\
\hline $\begin{array}{c}\text { No } \\
\text { Butir }\end{array}$ & $r_{x y}$ & $r_{\text {tabel }}$ & Ket. & Kep. & $\begin{array}{c}\text { No } \\
\text { Butir }\end{array}$ & $r_{x y}$ & $r_{\text {tabel }}$ & Ket. & Kep \\
\hline 1 & 0,267 & 0,244 & valid & Dipakai & 16 & 0,267 & 0,244 & valid & Dipakai \\
\hline 2 & 0,284 & 0,244 & valid & Dipakai & 17 & 0,261 & 0,244 & valid & Dipakai \\
\hline 3 & 0,249 & 0,244 & valid & Dipakai & 18 & 0,257 & 0,244 & valid & Dipakai \\
\hline 4 & 0,285 & 0,244 & valid & Dipakai & 19 & 0,256 & 0,244 & valid & Dipakai \\
\hline 5 & 0,248 & 0,244 & valid & Dipakai & 20 & 0,314 & 0,244 & valid & Dipakai \\
\hline 6 & 0,285 & 0,244 & valid & Dipakai & 21 & 0,273 & 0,244 & valid & Dipakai \\
\hline 7 & 0,255 & 0,244 & valid & Dipakai & 22 & 0,308 & 0,244 & valid & Dipakai \\
\hline 8 & 0,321 & 0,244 & valid & Dipakai & 23 & 0,350 & 0,244 & valid & Dipakai \\
\hline 9 & 0,246 & 0,244 & valid & Dipakai & 24 & 0,251 & 0,244 & valid & Dipakai \\
\hline 10 & 0,257 & 0,244 & valid & Dipakai & 25 & 0,252 & 0,244 & valid & Dipakai \\
\hline 11 & 0,356 & 0,244 & valid & Dipakai & 26 & 0,444 & 0,244 & valid & Dipakai \\
\hline 12 & 0,250 & 0,244 & valid & Dipakai & 27 & 0,252 & 0,244 & valid & Dipakai \\
\hline 13 & 0,313 & 0,244 & valid & Dipakai & 28 & 0,280 & 0,244 & valid & Dipakai \\
\hline 14 & 0,349 & 0,244 & valid & Dipakai & 29 & 0,252 & 0,244 & valid & Dipakai \\
\hline 15 & 0,367 & 0,244 & valid & Dipakai & 30 & 0,458 & 0,244 & valid & Dipakai \\
\hline
\end{tabular}

Pengujian reliabilitas kedua instrumen menggunakan rumus Kuder Richardson 20 dan Alpha Cronbach. Hasil uji reliabilitas tes kemampuan numerik diperoleh nilai reliabilitas sebesar 0,715 sehingga tes ini dikategorikan memiliki reliabilitas tinggi. Sedangkan hasil analisis reliabilitas tes kemampuan pemecahan masalah diperoleh nilai reliabilitas sebesar 0,706 sehingga tes ini dikategorikan memiliki reliabilitas tinggi.

Data hasil penelitian selanjutnya dianalisis dengan menggunakan analisis korelasi Pearson Product Moment (PPM). Sedangkan untuk mengetahui besarnya kontribusi kemampuan numerik terhadap kemampuan pemecahan masalah matematika siswa digunakan rumus koefisien determinasi. Besar $r^{2}$ dinyatakan dengan \% yang menunjukan besarnya kontribusi kemampuan numerik $(X)$ terhadap kemampuan pemecahan masalah $(Y)$, dengan rumus: $K P=r^{2} \times 100 \%$. Selanjutnya dilakukan uji $\mathrm{t}$ untuk melihat ada atau tidaknya hubungan yang positif dan signifikan antara kemampuan pemecahan masalah dan kemampuan numerik siswa.

152 | Volume 6, No 2, December 2018 


\section{HASIL DAN PEMBAHASAN}

Pengujian prasyarat analisis dengan statistik korelasi mensyaratkan data yang dianalisis berasal dari populasi yang berdistribusi normal dan berpola linear. Untuk itu, dilakukan uji normalitas dan uji linearitas. Uji normalitas menggunakan uji chi Kuadrat, sedangkan uji linearitas menggunakan uji F.

Uji normalitas ini dilakukan untuk mengetahui apakah sampel yang diteliti berasal dari populasi yang berdistribusi normal atau tidak. Uji normalitas dalam penelitian ini dilakukan dengan menggunakan bantuan Microsoft Excel. Uji normalitas dilakukan terhadap data kemampuan numerik dan data kemampuan pemecahan masalah matematika pada taraf signifikansi $\alpha=0,05$. Hasil analisis data kemampuan numerik menunjukkan bahwa nilai $\chi_{\text {hitung }}^{2}<\chi_{\text {tabel }}^{2}$ yaitu $11,04<15,51$, maka dapat dikatakan bahwa data kemampuan numerik siswa berasal dari populasi yang berdistribusi normal. Demikian pula hasil uji normalitas data kemampuan pemecahan masalah matematika siswa menunjukkan bahwa nilai $\chi_{\text {hitung }}^{2}<\chi_{\text {tabel }}^{2}$ yaitu $10,52<$ 15,51, maka dapat dikatakan bahwa data kemampuan pemecahan masalah matematika siswa berasal dari populasi yang berdistribusi normal.

Uji linieritas yang dimaksud dalam penelitian ini adalah untuk mengetahui apakah bentuk/model regresi $\mathrm{X}$ terhadap $\mathrm{Y}$ berpola linear atau tidak. Hasil uji linearitas menunjukkan bahwa nilai $f_{\text {hitung }}=-14,09$ dan nilai $f_{\text {tabel }}=2,06$. Karena $f_{\text {hitung }}<f_{\text {tabel }}$ yaitu $-14,09<2,06$ maka dapat disimpulkan bahwa data berpola linear.

Berdasarkan analisis data uji hipotesis, diperoleh hasil perhitungan korelasi antara kemampuan numerik dan kemampuan pemecahan masalah matematika siswa adalah 0,423. Sedangkan Hasil uji signifikansi diperoleh $t_{\text {hitung }}=6,88$ dengan $d k=n-2=214-2=212$ dan $\alpha=0,05$ maka diperoleh $t_{\text {tabel }}=1,65$. Ternyata $t_{\text {hitung }}>t_{\text {tabel }}$ yaitu 6,81 $>1,65$. Maka $H_{0}$ ditolak dan $H_{1}$ diterima atau dapat dikatakan terdapat hubungan yang positif dan signifikan antara kemampuan numerik dengan kemampuan pemecahan masalah matematika siswa kelas VIII SMP Negeri 1 Cibal. Harga koefisien korelasi $(r)$ yang diperoleh adalah 0,423 berada pada interval 0,40-0,599, ini berarti tingkat hubungannya cukup kuat. Koefisein korelasi bernilai positif sehingga arah hubungan tersebut positif. Kemudian besarnya sumbangan atau kontribusi kemampuan numerik terhadap kemampuan pemecahan masalah 
matematika siswa adalah $17,64 \%$ sedangkan sisanya dipengaruhi oleh faktor lain yang tidak diteliti.

Hasil penelitian ini menunjukkan bahwa kemampuan numerik memiliki hubungan positif dan signifikan terhadap kemampuan pemecahan masalah matematika siswa kelas VIII SMP Negeri 1 Cibal dan tingkat hubungan dari kedua variabel tersebut cukup kuat. Hasil penelitian ini didukung oleh hasil penelitian yang dilakukan oleh Libertus, Feigenson, \& Halberda (2013); Cragg \& Gilmore (2014); Fazio, Bailey, Thompson, \& Siegler (2014), yang menyatakan bahwa terdapat hubungan antara kemampuan numerik dengan kemampuan matematis lainnya termasuk kemampuan pemecahan masalah matematika.

\section{Pembahasan}

Berdasarkan hasil penelitian yang didukung oleh beberapa penelitian diatas, setiap pendidik perlu mengoptimalkan kemampuan numerik setiap siswa agar proses pembelajaran dan penyelesaian soal-soal matematika selalu berkaitan dengan perhitungan berjalan efektif. Pelajaran matematika akan lebih mudah dipelajari apabila mempunyai kemampuan numerik yang tinggi. Kemampuan numerik merupakan kemampuan khusus dalam berhitung, yang menunjang kemampuan siswa dalam memahami dan menyelesaikan soal yang membutuhkan kemampuan berpikir tingkat tinggi termasuk kemampuan pemecahan masalah (Cahyono, Masykuri, \& Ashadi, 2016). Kemampuan numerik meliputi pertanyaan tentang operasi dasar matematika seperti operasi penjumlahan, operasi pengurangan, operasi perkalian, dan operasi pembagian (Indrawati, 2013). Subtes kemampuan ini mengungkap bagaimana seseorang memahami ide-ide yang diekspresikan dalam bentuk angka-angka, dan bagaimana jelasnya seseorang dapat berpikir dan menalar dengan angkaangka. Dengan demikian, tes kemampuan numerik adalah tes untuk mengungkapkan kemampuan siswa untuk menalar dengan angka-angka, menggunakan atau memanipulasi relasi dengan angka, dan menguraikan secara logis.

Jika dicermati sebagian besar materi yang ada dalam mata pelajaran matematika membutuhkan banyak sekali penghitungan dan membutuhkan kemampuan khusus yang dapat menunjang proses penyelesaiannya. Proses penyelesaian ini yang akan mempengaruhi hasil belajar matematika yang dalam hal ini berkaitan dengan kognitif matematika siswa, dengan demikian hal yang paling mendasar dalam belajar matematika adalah diperlukannya kemampuan numerik atau kemampuan berhitung siswa karena kemampuan 154 | Volume 6, No 2, December 2018 
numerik merupakan salah satu faktor yang sangat berpengaruh terhadap hasil belajar matematika siswa. Semakin tinggi kemampuan numerik siswa maka hasil belajar juga akan semakin tinggi begitupun sebaliknya semakin rendah kemampuan numerik siswa maka hasil belajar juga semakin rendah.

Seseorang memiliki kemampuan numerik dapat dilihat ketika siswa mengerjakan soal matematika, misalnya soal perkalian, penjumlahan, pengurangan, pembagian, dan penarikan akar. Jika dipandang secara umum tes kemampuan numerik sering kali dirancang untuk mengetahui kekuatan logika dan kemampuan untuk menangani masalah secara terstruktur dan analitis.

Kemampuan numerik yang rendah menunjukkan kapasitas seseorang dalam memanipulasi atau menggunakan angka dalam menyelesaikan masalah dengan benar, lebih lanjut mereka juga mengatakan bahwa kemampuan berhitung rendah akan berpengaruh pada porspek pekerjaan, kesehatan fisik dan mental individu, dan status ekonomi suatu negara (Ademola, 2016). Carter (2005) berpendapat bahwa kemampuan numerik merupakan indikator kuat inteligensi umum, karena banyak tugas sehari-hari yang membutuhkan operasional aritmatika atau proses berpikir meskipun tidak melibatkan angka. Orang yang memiliki kemampuan numerik yang tinggi juga unggul dalam berbagai pekerjaan seperti sebagai auditor, konsultan bisnis, analisis finansial, guru matematika atau sains, surveyor, penasihat pajak, sekertaris perusahan, programmer komputer atau broker saham.

Kemampuan numerik menuntut seseorang berpikir secara logis, linier, teratur yang dalam belahan otak disebut berpikir konvergen atau dalam fungsi belahan otak, kemampuan numerik merupakan fungsi kerja otak bagian kiri. Jika dipadukan dengan kemampuan mengingat, maka kemampuan numerik dapat mengungkap kemampuan intelektual seseorang terutama kemampuan penalaran berhitung dan berpikir secara logis. Selain kemampuan penalaran hal lain yang akan terlihat juga adalah kemampuan kuantitatif, ketelitian dan keakuratan individu dalam mengerjakan sesuatu. Matematika erat kaitannya dengan angka atau bilangan yang merupakan konsep abstrak namun dapat digunakan untuk mengartikan fenomena kehidupan yang memerlukan perhitungan. Kemampuan pemecahan masalah merupakan kemampuan dasar seseorang dalam menyelesaikan suatu masalah yang melibatkan pemikiran kritis, logis, dan sistematis. Seseorang yang telah memiliki kemampuan numerik berarti dapat berpikir logis dan mudah menalar angka-angka sehingga mendukung pemikiran yang logis dan sistematis dalam menyelesaikan suatu masalah. 
Berdasarkan analisis data dalam penelitian ini, besar sumbangan atau kontribusi kemampuan numerik terhadap kemampuan pemecahan masalah matematika siswa adalah $17,64 \%$. Besar sumbangan ini menunjukan bahwa semakin tinggi kemampuan numerik siswa maka kemampuan pemecahan masalah juga semakin tinggi. Hal ini sejalan dengan penelitian yang dilakukan oleh Gunur, Sariyasa, dan Ardaa (2016) bahwa kemampuan numerik memberi kontribusi terhadap kemampuan pemecahan masalah yang didukung dengan pendekatan pembelajaran matematika realistik. Hasil penelitian ini menyimpulkan bahwa terdapat hubungan signifikan antara kemampuan numerik dengan kemampuan pemecahan masalah. Kontribusi kemampuan numerik terhadap kemampuan pemecahan masalah matematika siswa menunjukkan bahwa semakin tinggi kemampuan numerik siswa maka kemampuan pemecahan masalah juga semakin tinggi.

Walaupun terdapat kontribusi kemampuan numerik terhadap kemampuan pemecahan masalah matematika siswa sebesar 17,64\% yang peneliti anggap cukup besar, namun berdasarkan hasil wawancara tidak terstruktur dengan guru matematika diperoleh bahwa secara umum kemampuan matematis siswa masih rendah karena beberapa faktor lain yang mempengaruhi, diantaranya adalah semangat dan motivasi belajar yang kurang, pola pikir siswa yang lambat dan belum berkembang serta lingkungan sekolah dan lingkungan siswa berasal. Pernyataan guru tersebut sejalan dengan jawaban siswa ketika dimintai keterangan mengenai alasan rendahnya motivasi, semangat belajar dan pola pikir yang cukup lamban. Mereka menjelaskan bahwa secara umum lingkungan merupakan faktor yang cukup berpengaruh terhadap semangat dan pembentukan pola pikir siswa.

Jika dilihat secara geografis SMPN 1 Cibal terletak di wilayah Kelurahan Pagal Kecamatan Cibal. Kelurahan Pagal diapiti bagian timur desa Barang, bagian barat desa Golo Njuang, bagian utara desa Compang Cibal dan bagian selatan oleh desa Nenu. Walaupun terletak dikota kecamatan ternyata secara keseluruhan siswa yang masuk di SMPN 1 Cibal adalah siswa-siswa tamatan sekolah dasar yang berasal dari pedesaan.

Lingkungan pedesaan sebagai tempat mereka belajar tidak didukung oleh fasilitas dan kegiatan-kegiatan ekstrakulikuler seperti kurangnya bukubuku matematika, bimbingan belajar, organisasi di sekolah dan lain sebagainya yang mendorong siswa dalam meningkatkan motivasi, semangat belajar dan pola pikir. Faktor sosial ekonomi, dan pendidikan yang sulit terjangkau, tidak adanya sekolah pendidikan anak usia dini (PAUD) membentuk pola pikir siswa 156| Volume 6, No 2, December 2018 
yang santai, daya saing siswa yang rendah. Hal ini sejalan dengan hasil penelitian Kryst, Kotok, \& Bodovski, (2015) menunjukkan bahwa siswa TK pedesaan memiliki tingkat prestasi matematika rata-rata sedikit lebih rendah daripada rekan-rekan mereka di pinggiran kota. Selain itu, peningkatan ratarata dalam prestasi matematika dari taman kanak-kanak ke kelas delapan untuk anak-anak pedesaan lebih kecil daripada peningkatan untuk anak-anak pinggiran kota. Sedangkan hasil penelitian Graham \& Provost (2012), menunjukkan bahwa siswa yang bersekolah di sekolah pedesaan memiliki skor sains yang jauh lebih rendah dibandingkan siswa di kota. Selain itu, status sosial ekonomi keluarga memainkan peran penting dalam menentukan hasil pendidikan siswa pedesaan.

Melihat hasil penelitian ini, guru sebagai salah satu faktor yang ikut menentukan keberhasilan siswa diharapkan agar sering mengasah kemampuan siswa dengan memberi latihan soal-soal matematika dan menyampaikan materi dengan jelas sehingga bisa dipaham oleh siswa. Siswa juga diharapkan agar selalu mengasah kemampuan numerik dengan sering berlatih mengerjakan soal matematika secara rutin, dengan demikian kemampuan pemecahan masalah matematika akan semakin lebih baik pula.

\section{KESIMPULAN}

Terdapat hubungan yang positif dan signitifikan antara kemampuan numerik dengan kemampuan pemecahan masalah matematis siswa yang ditunjukkan dengan perolehan $t_{\text {hitung }}=6,88$ dengan $d k=n-2=214-2=$ 212 dan $\alpha=0,05$ maka diperoleh $t_{\text {tabel }}=1,65$. Jadi $t_{\text {hitung }}>t_{\text {tabel }}$ yaitu $6,81>1,65$. Besarnya sumbangan variabel kemampuan numerik terhadap kemampuan pemecahan masalah matematis siswa adalah 17, 64\%. Kontribusi variabel kemampuan numerik tersebut menunjukkan bahwa semakin baik kemampuan numerik seseorang maka semakin baik pula kemampuan pemecahan masalahnya.

\section{DAFTAR PUSTAKA}

Badru, A. K. (2016). Problem-based instructional strategy and numerical ability as determinants of senior secondary achievement in mathematics. Journal of Education and Practice, 7(13), 89-95. Retrieved from https:/ / files.eric.ed.gov/fulltext/EJ1102799.pdf

Cahyono, T. D., Masykuri, M., \& Ashadi. (2016). Kontribusi kemampuan numerik dan kreativitas terhadap prestasi belajar siswa pada materi 
pokok hidrolisis kelas XI MIA1 dan XI MIA5 SMA Negari 2 Karanganyar tahun pelajaran 2015/2016. Jurnal Pendidikan Kimia (JPK), 5(2), 81-88. Retrieved from http://jurnal.fkip.uns.ac.id/index.php/kimia/article/view/8374/6145

Carter, P. (2005). The complete book of intelligence tests. England: Wiley.

Cragg, L., \& Gilmore, C. (2014). Skills underlying mathematics: The role of executive function in the development of mathematics proficiency. Trends in Neuroscience and Education, 3(2), 63-68. Retrieved from https://www.sciencedirect.com/science/article/pii/S221194931300042 2

Eviyanti, C. Y., Surya, E., Syahputra, E., \& Simbolon, M. (2017). Improving the students' mathematical problem solving ability by applying problem based learning model in VII grade at SMPN 1 Banda Aceh Indonesia. International Journal of Novel Research, 4(2), 138-144. Retrieved from https:// www.researchgate.net/publication/318529138_Improving_the _Students'_Mathematical_Problem_Solving_Ability_by_Applying_Prob lem_Based_Learning_Model_in_VII_Grade_at_SMPN_1_Banda_Aceh_I ndonesia

Fazio, L. K., Bailey, D. H., Thompson, C. A., \& Siegler, R. S. (2014). Relations of different types of numerical magnitude representations to each other and to mathematics achievement. Journal of Experimental Child Psychology, 123, 53-72. Retrieved from http://www.psy.cmu.edu/ siegler/2014Fazioetal.pdf

Fuadi, I., Minarni, A., \& Banjarnahor, H. (2017). Analysis of students' mathematical problem solving ability in IX grade at Junior High School Ar-Rahman Percut. International Journal of Novel Research in Education and Learning, 4(2), 153-159.

Graham, S. E., \& Provost, L. E. (2012). Mathematics achievement gaps between suburban students and their rural and urban peers increase over time. Carsey Institute, (52), 1-8. Retrieved from https:/ / files.eric.ed.gov/fulltext/ED535962.pdf

Gunur, B., Sariyasa, \& Ardaa, I. M. (2016). Pengaruh pendidikan matematika realistik terhadap kemampuan pemecahan masalah matematika ditinjau dari kemampuan numerik siswa SMP Negeri 1 Cibal. Jurnal Pendidikan Dan Pembelajaran Matematika Indonesia, 5(1). Retrieved from 
http://119.252.161.254/e-journal/index.php/JPM/article/view/2129

Indrawati, F. (2013). Pengaruh kemampuan numerik dan cara belajar terhadap prestasi belajar matematika. Jurnal Formatif, 3(3), 215-223. Retrieved from http://journal.lppmunindra.ac.id/index.php/Formatif/article/downlo ad/126/122

Kryst, E. L., Kotok, S., \& Bodovski, K. (2015). Rural/ urban disparities in science achievement in post-socialist countries: The evolving influence of socioeconomic status. Global Education Review, 2(4), 60-77. Retrieved from http://ger.mercy.edu/index.php/ger/article/download/179/156

Lagur, D. S., Makur, A. P., \& Ramda, A. H. (2018). Pengaruh model pembelajaran kooperatif tipe numbered head together terhadap kemampuan komunikasi matematis. Mosharafa: Jurnal Pendidikan Matematika, 7(3), 357-368. Retrieved from https://journal.institutpendidikan.ac.id/index.php/mosharafa/article /download/mv7n3_5/pdf

Libertus, M. E., Feigenson, L., \& Halberda, J. (2013). Numerical approximation abilities correlate with and predict informal but not formal mathematics abilities. Journal of Experimental Child Psychology, 116(4), 829-838. Retrieved from https://www.ncbi.nlm.nih.gov/pmc/articles/pmc3796771/

Makur, A. P., Prahmana, R. C. I., \& Gunur, B. (2018). Kemampuan berpikir tingkat tinggi, peserta osk matematika tingkat sd, dan strategi think, talk, and write. Jurnal Pendidikan Matematika, 12(2), 23-32. Retrieved from https:// ejournal.unsri.ac.id/index.php/jpm/article/view/5677

National Council of Teachers Mathematics. (2000). Principle and standart for school mathematics. Reston, VA: NCTM.

Ramda, A. H., Prahmana, R. C. I., Mulu, H., \& Gunur, B. (2018). Kemampuan konservasi panjang pada siswa usia 6-7. Jurnal Gantang, 3(2), 109-116.

Saragih, S., \& Habeahan, W. L. (2014). The improving of problem solving ability and students' creativity mathematical by using problem based learning in SMP Negeri 2 Siantar. Journal of Education and Practice, 5(35), 123-133.

Suherman, E. (2001). Strategi pembelajaran matematika kontemporer. Bandung: JICA-UPI. 
Suparlan, A. J. (2009). Pengaruh minat dan kecerdasan numerik terhadap prestasi belajar matematika siswa. EduMa, 1(2), 129-137. Retrieved from https://anzdoc.com/pengaruh-minat-dan-kecerdasan-numerikterhadap-prestasi-bela.html

Utami, R. W., \& Wutsqa, D. U. (2017). Analisis kemampuan pemecahan masalah matematika dan self-efficacy siswa SMP Negeri di Kabupaten Ciamis. Jurnal Riset Pendidikan Matematika, 4(2), 166-175. Retrieved from https://journal.uny.ac.id/index.php/jrpm/article/view/14897/10186 